\title{
Radiation of members of the Soroseris hookeriana complex (Asteraceae) on the Qinghai-Tibetan Plateau and their proposed taxonomic treatment
}

\author{
La-Mei Heng', Yu-Lin Zheng', Yong-Bao Zhao', Yu-Jin Wang' \\ I State Key Laboratory of Grassland Agro-Ecosystem, School of Life Sciences, Lanzhou University, Lanzhou \\ 730000, PR China
}

Corresponding author: Yu-Jin Wang (wangyujin@lzu.edu.cn)

Academic editor:P. de Lange | Received 20 September 2018 | Accepted 27 November 2018 | Published 20 December 2018

Citation: Heng L-M, Zheng Y-L, Zhao Y-B, Wang Y-J (2018) Radiation of members of the Soroseris hookeriana complex (Asteraceae) on the Qinghai-Tibetan Plateau and their proposed taxonomic treatment. PhytoKeys 114: 11-25. https:// doi.org/10.3897/phytokeys.114.29914

\begin{abstract}
The existence of intermediate types is a major obstacle that can hinder the circumscription of species. Elucidating the mechanism responsible for intermediate types is essential for achieving a reasonable taxonomical treatment. In this study, we explored the evolutionary history and taxonomic treatment of the Soroseris hookeriana (C.B.Clarke) Stebbins complex, which comprises six named taxa that may be taxonomically distinct and are all native to the Qingha-Tibetan Plateau (QTP). We made an investigation across the distribution range of Soroseris Stebbins and sampled 27 populations, mostly from the complex. Internal transcribed spacer (ITS) and two chloroplast loci were sequenced and analysed using the neighbourjoining and Bayesian inference methods. The resulting phylogenies show no well supported inconsistence in topologies, in line with the lack of incongruence detected by the length difference test. However, all the trees were largely unresolved within $S$. hookeriana complex, irrespective of the optimality criterion employed. We interpret these results as an experience of radiation, which is a common process for native genera on the QTP. Thus, we suggest that all of the morphotypes might be different forms, generated by incipient speciation due to recent explosive differentiation, possibly triggered by the drastic environmental changes of the QTP. Given their evolutionary history, we propose a pragmatic method for treating all of these species as subspecies with a total of four new combinations.
\end{abstract}

\section{Keywords}

Radiation, Soroseris hookeriana complex, taxonomic treatment, Asteraceae

Copyright La-Mei Heng et al. This is an open access article distributed under the terms of the Creative Commons Attribution License (CC BY 4.0), which permits unrestricted use, distribution, and reproduction in any medium, provided the original author and source are credited. 


\section{Introduction}

The description and delimitation of species in an evolutionary framework is essential for understanding patterns of biodiversity and distribution, as well as when assessing conservation strategies for natural resources (Liu 2016; Yang 2016). However, species complexes, comprising a few distinct morphotypes with a series of intermediates at the species level, are a difficult problem for taxonomists (Liu 2016). These intermediates might be derived via various mechanisms such as intraspecies variation, interspecies hybridisation, convergent evolution or radiation (Wang et al. 2004; Liu et al. 2006). Increasing studies suggest that DNA sequences can be employed to elucidate the mechanisms responsible for intermediate types (Su et al. 2015; Zheng et al. 2017).

Soroseris is a genus comprising seven species and all are endemic to the QinghaTibetan Plateau (QTP) according to the latest comprehensive revision (Shi and Kilian 2011). Despite its restricted distribution and the paucity of species, this genus contains two species complexes. The first referred to as the Soroseris glomerata (Decne.) Stebbins complex comprises $S$. glomerata and five possibly distinct species, all of which have been treated as S. glomerata in some studies (Stebbins 1940; Shih 1997; Shi and Kilian 2011). Two were recognised as independent species in the latest revision, i.e. S. pumila Stebbins and S. depressa (Hook. f. \& Thomson) J. W. Zhang, N. Kilian \& H. Sun, whereas three, i.e. S. bellidifolia (Hand.-Mazz.) Stebbins, S. deasyi Stebbins, and $S$. rosularis (Diels) Stebbins, were accepted as synonyms with a comment that it is appropriate to recognise them as subspecies, awaiting more studies on variation and distribution (Shi and Kilian 2011). Phylogenetic studies, based on either nuclear the internal transcribed spacer (ITS) or plastid regions, showed that $S$. glomerata could be resolved into at least two distantly related clades (Zhang et al. 2011), thereby implying that it may not be monophyletic.

The second species complex, referred to as the $S$. hookeriana (C.B.Clarke) Stebbins complex, comprises $S$. hookeriana and five possibly independent species, where one was accepted as S. erysimoides (Hand.-Mazz.) C. Shih in the latest revision, whereas the other four, i.e. S. occidentalis (Stebbins) Tzvelev, S. hirsuta (J. Anthony) C. Shih, S. gillii (S. Moore) Stebbins and S. gillii subsp. handelii Stebbins, were treated as synonyms of S. hookeriana (Shi and Kilian 2011). Several other treatments have been proposed and we listed four of them in Table 1 (Stebbins 1940; Shih 1993, 1997; Shi and Kilian 2011). These taxa have all been treated at species rank except for $S$. gillii subs. handelii, yet in other treatments have been treated as synonyms or subspecies, notably, under different species (Stebbins 1940; Shih 1993; Tzvelev 2007; Shi and Kilian 2011). This complicated taxonomical controversy undoubtedly reflects the difficulty in delimitating taxa within Soroseris in terms of their morphology.

In addition to the controversial treatments mentioned above, the circumscription of Soroseris is also disputed. For example, two species of Syncalathium Lipschitz are included in Soroseris in some systems (Shih 1993). Recently, a number of studies based on pollen, achene morphology, karyotypes and multiple DNA loci (Zhang et al. 2007, 
Table I. Different taxonomical treatments of the possible members of the Soroseris hookeriana complex. FRPS: Flora Reipublicae Popularis Sinicae; FOC: Flora of China.

\begin{tabular}{llll}
\hline \multicolumn{1}{c}{ Stebbins (1940) } & \multicolumn{1}{c}{ Shih C (1993) } & \multicolumn{1}{c}{ FRPS (1997) } & \multicolumn{1}{c}{ FOC (2011) } \\
\hline S. gillii subsp. typica & S. trichocarpa & S. gillii & S. hookeriana \\
S. gillii subsp. occidentalis & S. hirsuta & S. hirsuta & S. hookeriana \\
S. gillii subsp. hirsuta & S. hirsuta & S. hirsuta & S. hookeriana \\
S. gillii subsp. handelii & S. hirsuta & S. hirsuta & S. hookeriana \\
S. hookeriana subsp. typica & S. hookeriana & S. hookeriana & S. hookeriana \\
S. hookeriana subsp. erysimoides & S. erysimoides & S. erysimoides & S. erysimoides \\
S. bellidifolia & S. hirsuta & S. hirsuta & S. glomerata \\
\hline
\end{tabular}

2013; Zhang and Sun 2011; Peng et al. 2013) have supported the circumscription of the latest revision of Soroseris (Shi and Kilian 2011), but there are some slight differences compared with the first revision (Stebbins 1940). In morphological terms, the genus is circumscribed mainly based on a densely crowded capitula on a thick and hollow stem, with two layers of phyllaries, where the outer layer are much smaller (Stebbins 1940). Molecular phylogenetic analyses indicate that Syncalathium might be the sister group of Soroseris, in line with their similarity in morphology, such as densely crowded capitula (Zhang et al. 2011), the chromosome number and the preferred habitat in high altitude (Zhang et al. 2007; Ying and Yang 2011; Yang et al. 2017).

Previous studies have resolved the circumscription and sister (Syncalathium) of Soroseris, but the delimitation within the two species complexes remains unresolved (Zhang and Sun 2011). A major problem is the lack of samples of multiple individuals and comparisons of intra-/interspecies genetic diversity (Zhang and Sun 2011). In this study, we focused on the $S$. hookeriana complex. We sampled multiple individuals and sequenced several loci in order: (1) to clarify the mechanisms responsible for the complicated relationships in terms of morphology in this species complex; and (2) to revise the taxonomy of the $S$. hookeriana complex. We supposed that, if hybridisation was documented, the parental species and the possible cases of hybridisation could be recognised or, if radiation was indicated, the number of species within the complex could be greatly reduced.

\section{Materials and methods}

\section{Taxon sampling}

In total, from the QTP, we collected 35 individuals from 27 populations belonging to Soroseris and two individuals from Syncalathium as an outgroup, according to a previous study (Zhang et al. 2011) and all the voucher specimens were deposited in the herbarium of Lanzhou University. The samples from Soroseris were identified as belonging to six species, with five from the latest revision (Shi and Kilian 2011) 
Table 2. Taxa, collection localities, vouchers (or the references for those downloaded from NCBI) and their GenBank accession numbers.

\begin{tabular}{|c|c|c|c|c|c|c|}
\hline $\begin{array}{c}\text { Taxon } \\
\text { (FOC, 2011) }\end{array}$ & Collection locality & $\begin{array}{l}\text { Latitude } \\
\left({ }^{\circ} \mathrm{N}\right)\end{array}$ & $\begin{array}{l}\text { Longitude } \\
\left({ }^{\circ} \mathrm{E}\right)\end{array}$ & $\begin{array}{l}\text { Altitude } \\
\text { (m) }\end{array}$ & Voucher & $\begin{array}{c}\text { Genbank number (ITS, } \\
m a t K, p s b A \text {-trnH) }\end{array}$ \\
\hline \multirow[t]{12}{*}{ S. erysimoides } & Cuona, Tibet, China & 27.9269 & 91.8789 & 4519 & $\begin{array}{l}\text { Y.-J. Wang, CN30 } \\
\text { (LZU) }\end{array}$ & $\begin{array}{c}\text { MG932859; MG946722; } \\
\text { MG932893 }\end{array}$ \\
\hline & Cuona, Tibet, China & 27.9269 & 91.8789 & 4519 & $\begin{array}{l}\text { Y.-J. Wang, CN47 } \\
\text { (LZU) }\end{array}$ & $\begin{array}{c}\text { MG932861; MG946724; } \\
\text { MG932895 }\end{array}$ \\
\hline & Cuona, Tibet, China & 27.9269 & 91.8789 & 4519 & $\begin{array}{l}\text { Y.-J. Wang, CN48 } \\
\text { (LZU) }\end{array}$ & $\begin{array}{c}\text { MG932862; MG946725; } \\
\text { MG932896 }\end{array}$ \\
\hline & Cuona, Tibet, China & 27.9269 & 91.8789 & 4519 & $\begin{array}{l}\text { Y.-J. Wang, CN49 } \\
\text { (LZU) }\end{array}$ & $\begin{array}{c}\text { MG932863; MG946726; } \\
\text { MG932897 }\end{array}$ \\
\hline & Cuona, Tibet, China & 27.9269 & 91.8789 & 4519 & $\begin{array}{l}\text { Y.-J. Wang, CN50 } \\
\text { (LZU) }\end{array}$ & $\begin{array}{c}\text { MG932864; MG946727; } \\
\text { MG932898 }\end{array}$ \\
\hline & Cuona, Tibet, China & 27.9269 & 91.8789 & 4519 & $\begin{array}{l}\text { Y.-J. Wang, CN51 } \\
\text { (LZU) }\end{array}$ & $\begin{array}{c}\text { MG932865; MG946728; } \\
\text { MG932899 }\end{array}$ \\
\hline & Geermu, Qinghai, China & 35.4158 & 96.3409 & 4665 & $\begin{array}{c}\text { Y.-J. Wang, GEM3 } \\
\text { (LZU) }\end{array}$ & $\begin{array}{c}\text { MG932858; MG946721; } \\
\text { MG932892 }\end{array}$ \\
\hline & Yadong, Tibet, China & 27.5518 & 88.9306 & 3059 & $\begin{array}{l}\text { Y.-J. Wang, YD46 } \\
\text { (LZU) }\end{array}$ & $\begin{array}{c}\text { MG932860; MG946723; } \\
\text { MG932894 }\end{array}$ \\
\hline & Xingu, Sichuan, China & - & - & - & Zhang et al. 2011 & $\begin{array}{c}\text { HQ436213; JF956518; } \\
\text { HQ436180 }\end{array}$ \\
\hline & Tibet, China & - & - & - & Zhang et al. 2011 & $\begin{array}{c}\text { JF978800; JF956516; } \\
\text { JN047244 }\end{array}$ \\
\hline & Deqin, Yunnan, China & - & - & - & Zhang et al. 2011 & $\begin{array}{c}\text { HQ436212; JF956517; } \\
\text { HQ436179 }\end{array}$ \\
\hline & Sichuan, China & - & - & - & Zhang et al. 2011 & $\begin{array}{c}\text { JF978799; JF956515; } \\
\text { JN047243 }\end{array}$ \\
\hline \multirow[t]{16}{*}{ S. hookeriana } & Chayu, Tibet, China & 29.3252 & 97.0390 & 4705 & $\begin{array}{l}\text { Y.-J. Wang, CY39 } \\
\text { (LZU) }\end{array}$ & $\begin{array}{c}\text { MG932868; MG946742; } \\
\text { MG932910 }\end{array}$ \\
\hline & Chayu, Tibet, China & 29.3252 & 97.0390 & 4705 & $\begin{array}{l}\text { Y.-J. Wang, CY53 } \\
\text { (LZU) }\end{array}$ & $\begin{array}{c}\text { MG932869; MG946743; } \\
\text { MG932917 }\end{array}$ \\
\hline & $\begin{array}{l}\text { Daocheng, Sichuan, } \\
\text { China }\end{array}$ & 29.2953 & 100.1466 & 4404 & $\begin{array}{l}\text { Y.-J. Wang, DC9 } \\
\text { (LZU) }\end{array}$ & $\begin{array}{c}\text { MG932871; MG932921; } \\
\text { MG932921 }\end{array}$ \\
\hline & $\begin{array}{l}\text { Kangding, Sichuan, } \\
\text { China }\end{array}$ & 29.4446 & 101.4339 & 4657 & $\begin{array}{l}\text { Y.-J. Wang, KD11 } \\
\text { (LZU) }\end{array}$ & $\begin{array}{l}\text {--; MG946729; } \\
\text { MG932900 }\end{array}$ \\
\hline & $\begin{array}{l}\text { Kangding, Sichuan, } \\
\text { China }\end{array}$ & 30.0411 & 101.9532 & 2861 & $\begin{array}{l}\text { J.-Q. Liu, KD54 } \\
\text { (LZU) }\end{array}$ & $\begin{array}{c}\text { MG932870; MG946732; } \\
\text { MG932918 }\end{array}$ \\
\hline & $\begin{array}{l}\text { Kangding, Sichuan, } \\
\text { China }\end{array}$ & 30.0411 & 101.9532 & 2861 & $\begin{array}{l}\text { Y.-J. Wang, KD7 } \\
\text { (LZU) }\end{array}$ & $\begin{array}{c}\text { MG932877; MG946750; } \\
\text { MG932914 }\end{array}$ \\
\hline & $\begin{array}{c}\text { Xiangcheng, Sichuan, } \\
\text { China }\end{array}$ & 28.9312 & 99.7835 & 2927 & $\begin{array}{l}\text { Y.-J. Wang, XC10 } \\
\text { (LZU) }\end{array}$ & $\begin{array}{c}\text { MG932876; MG946747; } \\
\text { MG932915 }\end{array}$ \\
\hline & Xiaojin, Sichuan, China & 30.5473 & 102.5373 & 4519 & $\begin{array}{l}\text { Y.-J. Wang, XJ4 } \\
\text { (LZU) }\end{array}$ & $\begin{array}{c}\text { MG932873; MG946739; } \\
\text { MG932911 }\end{array}$ \\
\hline & Xiaojin, Sichuan, China & 30.5473 & 102.5373 & 4519 & $\begin{array}{l}\text { Y.-J. Wang, XJ5 } \\
\text { (LZU) }\end{array}$ & $\begin{array}{c}\text { MG932874; MG946740; } \\
\text { MG932914 }\end{array}$ \\
\hline & Xiaojin, Sichuan, China & 30.5473 & 102.5373 & 4519 & $\begin{array}{l}\text { Y.-J. Wang, XJ6 } \\
\text { (LZU) }\end{array}$ & $\begin{array}{c}\text { MG932875; MG946741; } \\
\text { MG932920 }\end{array}$ \\
\hline & Zhiduo, Qinghai, China & 33.5845 & 96.3409 & 4689 & $\begin{array}{l}\text { Y.-J. Wang, ZD2 } \\
\text { (LZU) }\end{array}$ & $\begin{array}{c}\text { MG932866; MG932902; } \\
\text { MG932902 }\end{array}$ \\
\hline & Sichuan, China & - & - & - & Zhang et al. 2011 & $\begin{array}{c}\text { HQ446097; JF956522; } \\
\text { JN047246 }\end{array}$ \\
\hline & Sichuan, China & - & - & - & Zhang et al. 2011 & $\begin{array}{c}\text { HQ436227; JF956521; } \\
\text { JN047245 }\end{array}$ \\
\hline & $\begin{array}{l}\text { Kangding, Sichuan, } \\
\text { China }\end{array}$ & - & - & - & Zhang et al. 2011 & $\begin{array}{c}\text { HQ436214; JF956520; } \\
\text { HQ436181 }\end{array}$ \\
\hline & Cuomei, Tibet, China & 28.7853 & 91.7549 & 5048 & $\begin{array}{l}\text { Y.-J. Wang, CN25 } \\
\text { (LZU) }\end{array}$ & $\begin{array}{c}\text { MG932883; MG946734; } \\
\text { MG932905 }\end{array}$ \\
\hline & Dingri, Tibet, China & 28.5755 & 87.1136 & 4305 & $\begin{array}{l}\text { Y.-J. Wang, DR55 } \\
\text { (LZU) }\end{array}$ & $\begin{array}{c}\text { MG932886; MG946737; } \\
\text { MG932919 }\end{array}$ \\
\hline
\end{tabular}




\begin{tabular}{|c|c|c|c|c|c|c|}
\hline $\begin{array}{c}\text { Taxon } \\
(\text { FOC, 2011) } \\
\end{array}$ & Collection locality & $\begin{array}{l}\text { Latitude } \\
\left({ }^{\circ} \mathrm{N}\right)\end{array}$ & $\begin{array}{c}\text { Longitude } \\
\left({ }^{\circ} \mathrm{E}\right)\end{array}$ & $\begin{array}{l}\text { Altitude } \\
(\mathbf{m})\end{array}$ & Voucher & $\begin{array}{c}\text { Genbank number (ITS, } \\
m a t K, p s b A \text {-trnH) }\end{array}$ \\
\hline \multirow[t]{10}{*}{ S. hookeriana } & Dangxiong, Tibet, China & 29.9018 & 90.1370 & 5400 & $\begin{array}{l}\text { Y.-J. Wang, DX17 } \\
\text { (LZU) }\end{array}$ & $\begin{array}{c}\text { MG932882; MG946733; } \\
\text { MG932901 }\end{array}$ \\
\hline & Dangxiong, Tibet, China & 29.9018 & 90.1370 & 5400 & $\begin{array}{l}\text { Y.-J. Wang, DX43 } \\
\text { (LZU) }\end{array}$ & $\begin{array}{c}\text { MG932885; MG946736; } \\
\text { MG932912 }\end{array}$ \\
\hline & Longzi, Tibet, China & 28.6027 & 92.2142 & 4906 & $\begin{array}{l}\text { Y.-J. Wang, LZ27 } \\
\text { (LZU) }\end{array}$ & $\begin{array}{c}\text { MG932884; MG946735; } \\
\text { MG932906 }\end{array}$ \\
\hline & Longzi, Tibet, China & 28.6371 & 92.2175 & 5106 & $\begin{array}{l}\text { Y.-J. Wang, LZ52 } \\
\text { (LZU) }\end{array}$ & $\begin{array}{c}\text { MG932878; MG946749; } \\
\text { MG932916 }\end{array}$ \\
\hline & Yadong, Tibet, China & 27.5527 & 88.9315 & 3059 & $\begin{array}{l}\text { Y.-J. Wang, YD21 } \\
\text { (LZU) }\end{array}$ & $\begin{array}{c}\text { MG932867; MG946731; } \\
\text { MG932904 }\end{array}$ \\
\hline & $\begin{array}{l}\text { Hongshan, Yunnan, } \\
\text { China }\end{array}$ & - & - & - & Zhang et al. 2011 & $\begin{array}{c}\text { HQ436218; JF956532; } \\
\text { HQ436185 }\end{array}$ \\
\hline & Tibet, China & - & - & - & Zhang et al. 2011) & $\begin{array}{c}\text { JF978806; JF956530; } \\
\text { JN047250 }\end{array}$ \\
\hline & Longzi, Tibet, China & 28.6371 & 92.2175 & 5106 & $\begin{array}{l}\text { Y.-J. Wang, LZ33 } \\
\text { (LZU) }\end{array}$ & $\begin{array}{c}\text { MG932872; MG946738; } \\
\text { MG932909 }\end{array}$ \\
\hline & Cuona, Tibet, China & 27.9269 & 91.8788 & 4519 & $\begin{array}{l}\text { Y.-J. Wang, CN29 } \\
\text { (LZU) }\end{array}$ & $\begin{array}{c}\text { MG932880; MG946745; } \\
\text { MG932907 }\end{array}$ \\
\hline & Cuona, Tibet, China & 27.8476 & 91.8929 & 4732 & $\begin{array}{l}\text { Y.-J. Wang, CN32 } \\
\text { (LZU) }\end{array}$ & $\begin{array}{c}\text { MG932881; MG946746; } \\
\text { MG932908 }\end{array}$ \\
\hline \multirow[t]{5}{*}{ S. glomerata } & Angren, Tibet, China & 29.5021 & 86.2770 & 4753 & $\begin{array}{l}\text { Y.-J. Wang, AR18 } \\
\text { (LZU) }\end{array}$ & $\begin{array}{c}\text { MG932887; MG946744; } \\
\text { MG932922 }\end{array}$ \\
\hline & Tibet, China & - & - & - & Zhang et al. 2011 & $\begin{array}{c}\text { JF978802; JF956523; } \\
\text { JN047247 }\end{array}$ \\
\hline & $\begin{array}{c}\text { Daxueshan, Yunnan, } \\
\text { China }\end{array}$ & - & - & - & Zhang et al. 2011 & $\begin{array}{c}\text { HQ436217; JF956527; } \\
\text { HQ436184 }\end{array}$ \\
\hline & Deqin, Yunnan, China & - & - & - & Zhang et al. 2011 & $\begin{array}{c}\text { HQ436216; JF956528; } \\
\text { HQ436183 }\end{array}$ \\
\hline & Tibet, China & - & - & - & Zhang et al. 2011 & $\begin{array}{c}\text { JF978804; JF956525; } \\
\text { JN047248 }\end{array}$ \\
\hline \multirow[t]{2}{*}{ S. teres } & Yadong, Tibet, China & 27.5503 & 88.9316 & 3059 & $\begin{array}{l}\text { Y.-J. Wang, YD44 } \\
\text { (LZU) }\end{array}$ & $\begin{array}{c}\text { MG932888; MG946752; } \\
\text { MG932924 }\end{array}$ \\
\hline & Yadong, Tibet, China & 27.5503 & 88.9316 & 3059 & $\begin{array}{l}\text { Y.-J. Wang, YD45 } \\
\text { (LZU) }\end{array}$ & $\begin{array}{c}\text { MG932889; MG946753; } \\
\text { MG932925 }\end{array}$ \\
\hline \multirow[t]{2}{*}{ S. umbrella } & $\begin{array}{c}\text { Zhonggashan, Yunnan, } \\
\text { China }\end{array}$ & - & - & - & Zhang et al. 2011 & $\begin{array}{c}\text { HQ436197; HQ436164; } \\
\text { HQ436131 }\end{array}$ \\
\hline & $\begin{array}{l}\text { Hongshan, Yunnan, } \\
\text { China }\end{array}$ & - & - & - & Zhang et al. 2011 & $\begin{array}{c}\text { HQ436198; HQ436165; } \\
\text { HQ436132 }\end{array}$ \\
\hline Soroseris sp. & Chayu, Tibet, China & 29.3252 & 97.0390 & 4705 & $\begin{array}{l}\text { Y.-J. Wang, CY40 } \\
\text { (LZU) }\end{array}$ & $\begin{array}{c}\text { MG932879; MG946748; } \\
\text { MG932923 }\end{array}$ \\
\hline $\begin{array}{l}\text { Syncalathium } \\
\text { disciforme }\end{array}$ & Heishui, Sichuan, China & 32.1326 & 102.3633 & 4016 & $\begin{array}{l}\text { Y.-J. Wang, HS12 } \\
\text { (LZU) }\end{array}$ & $\begin{array}{c}\text { MG932890; MG946754; } \\
\text { MG932926 }\end{array}$ \\
\hline $\begin{array}{l}\text { Syncalathium } \\
\text { kawaguchii }\end{array}$ & Luozha, Tibet, China & 28.2504 & 91.0481 & 4112 & $\begin{array}{l}\text { Y.-J. Wang, LZ24 } \\
\text { (LZU) }\end{array}$ & $\begin{array}{c}\text { MG932891; MG946755; } \\
\text { MG932927 }\end{array}$ \\
\hline
\end{tabular}

and one that differed from all the known species (Voucher: CY40). The members of $S$. hookeriana complex, S. hookeriana and S. erysimoides, total up to thirty individuals and they could be further sorted into at least eight morphotypes. Six of them are largely comparable to six subspecies recognised by Stebbins (Stebbins 1940), although more or less variations exist. Two of them seem to intermediate amongst different subspecies and here we named them Intermediate A and B, tentatively. A morphological comparison amongst these specimens, together with several related ones, is listed in Suppl. material 1. In addition, sequences from 17 individuals belonging to three species, including nine from the $S$. hookeriana complex and one we 
failed to collect, i.e. S. umbrella (Franch.) Stebbins, were downloaded from GenBank, which were all obtained in the study by Zhang et al. (Zhang et al. 2011). All of the samples, voucher locations and GenBank numbers used in the analysis are listed in Table 2.

\section{DNA extraction, PCR amplification, and sequencing}

Genomic DNA was extracted from dried leaves in silica gel using the CTAB method (Doyle and Dickson 1987). Three regions ( $p s b A-t r n H$, matK and ITS) were amplified and sequenced with the primers from published literature (White et al. 1990; Sang et al. 1997; Ford et al. 2009). The PCR reaction mixture comprising $25 \mu \mathrm{l}$ was prepared and amplified according to the procedure described by Wang et al. (Wang et al. 2009). The PCR products were sent to the Beijing Genomics Institute for commercial sequencing. Sequences were aligned using CLUSTALX v.2.1 (Thompson et al. 1997) with the default settings and adjusted manually with Bioedit v.7.0.5 (Hall 1999). All of the sequences were registered in GenBank (Table 2).

\section{Data analysis}

Three datasets were constructed for the ITS sequences, the combination of $p s b A-\operatorname{trn} H$ and mat $K$ and the combination of all the three fragments. For the first two datasets, genetic distance was calculated with Mega (Tamura et al. 2013) under Kimura's two-parameter (K-2P) model (Kimura 1980). For the last one, the congruence between ITS and the other two fragments was evaluated using the incongruence length difference (ILD) test in PAUP* 4.0b10. For all the three data sets, neighbour-joining (NJ) and Bayesian inference (BI) methods were employed to reconstruct the phylogenetic relationships. The NJ trees were built using PAUP version $4 \mathrm{~b} 10$ with K-2P model (Swofford 2003). Node support was assessed based on bootstrap percentages (BP) of 100000 replicates. BI was implemented using MrBayes on XSEDE (v3.2.6) (Ronquist et al. 2012) and the optimal models for each marker were determined according to Akaike's information criterion (Akaike 1974) using jModelTest2 on XSEDE (v2.1.6) (Darriba et al. 2012).

\section{Results}

\section{ITS sequences}

The aligned ITS dataset comprised 607 base pairs (bp) with 58 variable sites, where 36 sites were potentially parsimony informative. A total of 12 mosaic sites are detected from eight individuals, mostly with one or two. The K-2P distance, ranged from 0 to $2.4 \%$, is $0.6 \%$ on average within the ingroup, while $0.3 \%$ on average or $1 \%$ maxi- 


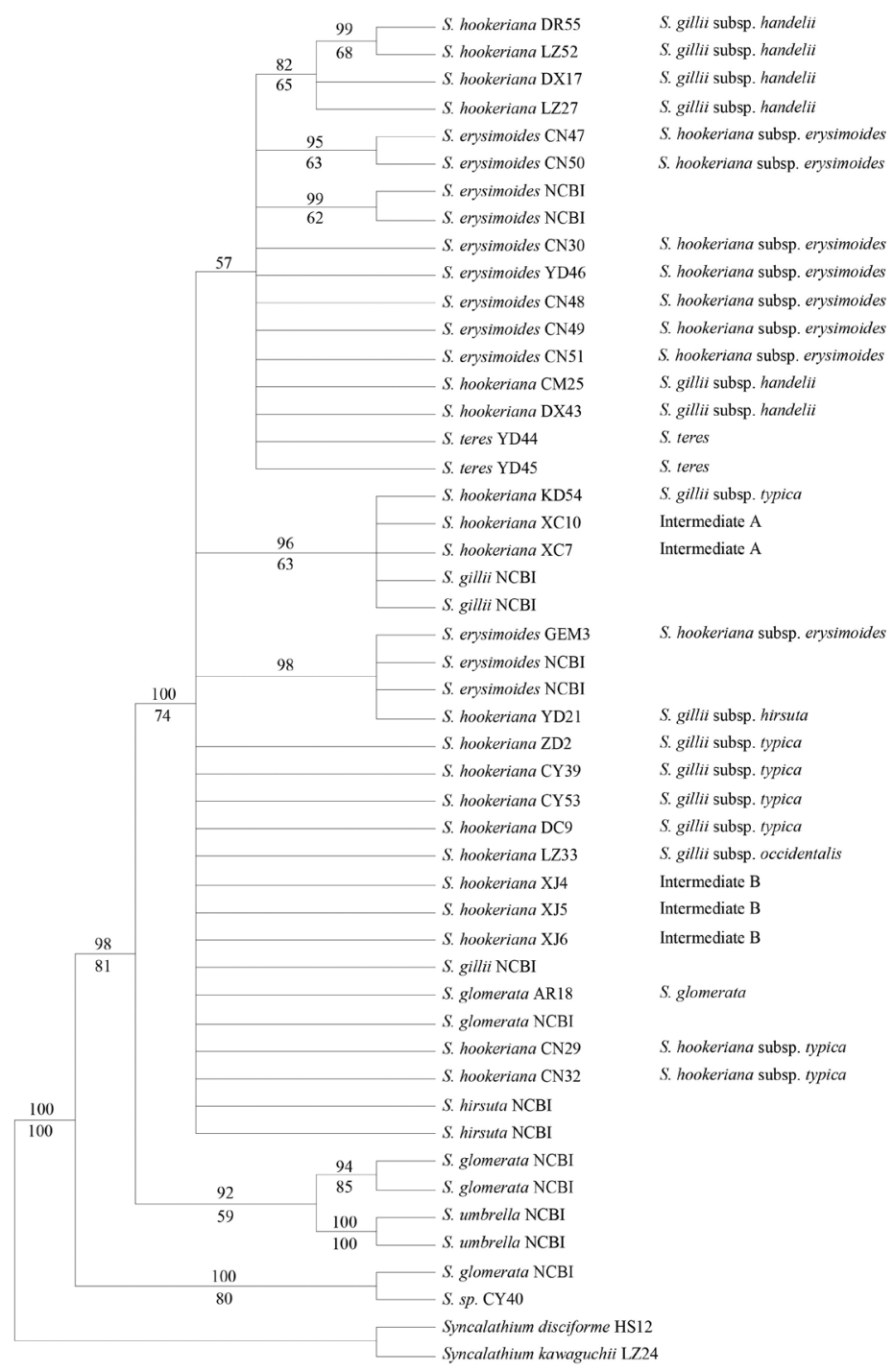

S. hookeriana subsp. handelii

S. hookeriana subsp. handelii

S. hookeriana subsp. handelii

S. hookeriana subsp. handelii

S. hookeriana subsp. erysimoides

S. hookeriana subsp. erysimoides

S. hookeriana complex

S. hookeriana complex

S. hookeriana subsp. erysimoides

S. hookeriana subsp. erysimoides

S. hookeriana subsp. erysimoides

S. hookeriana subsp. erysimoides

S. hookeriana subsp. erysimoides

S. hookeriana subsp. handelii

S. hookeriana subsp. handelii

S. hookeriana complex

S. hookeriana complex

S. hookeriana subsp. gillii

S. hookeriana complex

S. hookeriana complex

S. hookeriana complex

S. hookeriana complex

S. hookeriana subsp. erysimoides

S. hookeriana complex

S. hookeriana complex

S. hookeriana subsp. hirsuta

S. hookeriana subsp. gillii

S. hookeriana subsp. gillii

S. hookeriana subsp. gillii

S. hookeriana subsp. gillii

S. hookeriana subsp. occidentalis

S. hookeriana complex

S. hookeriana complex

S. hookeriana complex

S. hookeriana complex

S. hookeriana complex

S. hookeriana complex

S. hookeriana subsp. typica

S. hookeriana subsp. typica

S. hookeriana complex

S. hookeriana complex

Figure I. The 50\% majority rule consensus tree derived from Bayesian inference of the nuclear internal transcribed spacer. Posterior probabilities and bootstrap percentages are indicated above and below the branches, respectively. The samples named according to FOC (2011) or NCBI, Stebbins (1940) and the present study are listed from left to right.

mally within the complex. The NJ tree was mostly congruent in terms of its topology with the $50 \%$ majority rule consensus tree derived from Bayesian analysis and the latter is shown in Fig. 1. The in-group samples were resolved into three clades. The first clade, which was a sister to the other two, comprised part of $S$. glomerata and a species that we failed to identify $(\mathrm{BI}=100 \%, \mathrm{BP}=80 \%)$. The second clade contained two S. glomerata and S. umbrella sequences $(\mathrm{BI}=92 \%, \mathrm{BP}=59 \%)$. The third clade 


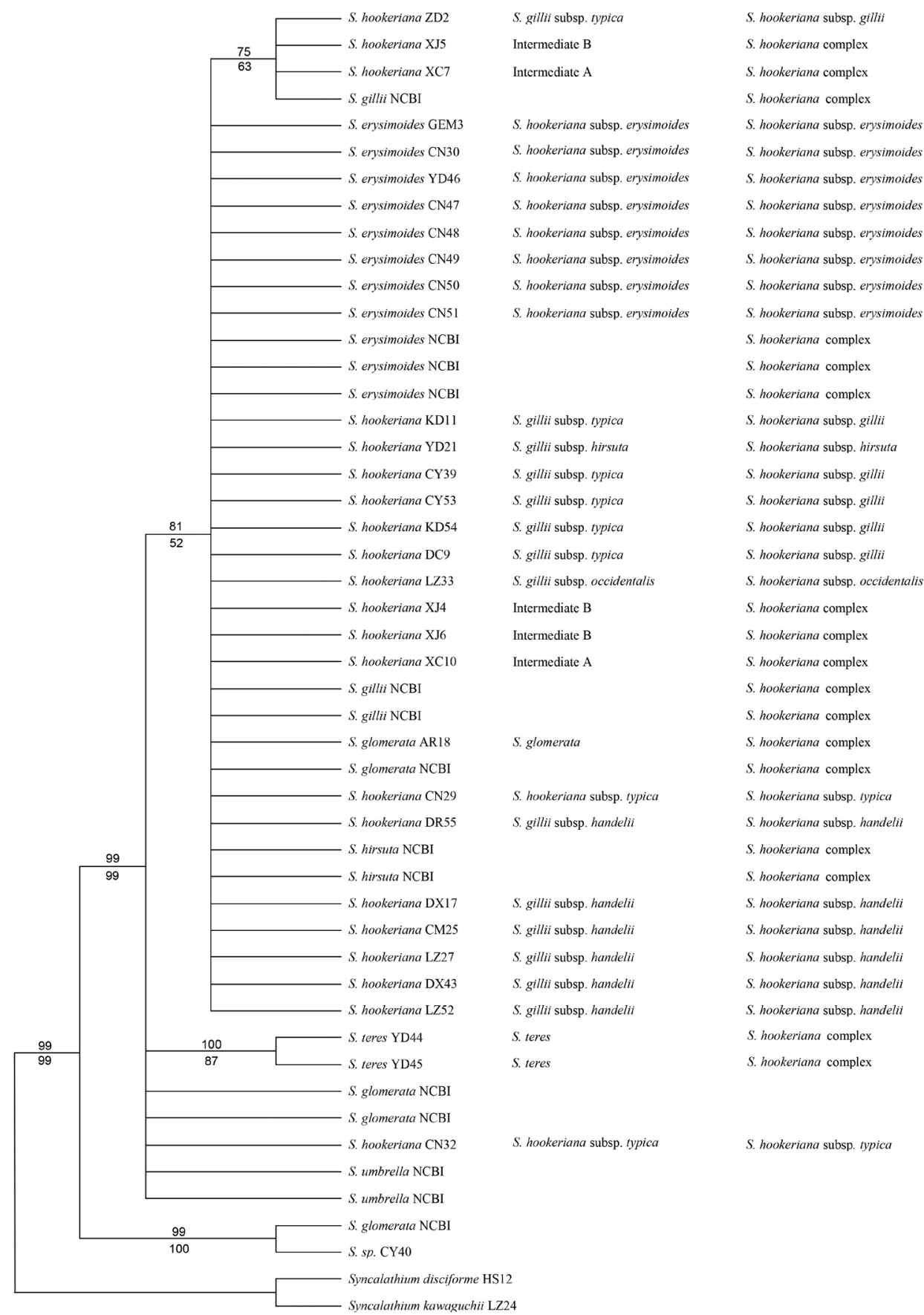

Figure 2. The $50 \%$ majority rule consensus tree derived from Bayesian inference of the combined sequences of $p s b A$-trn $H$ and matK. Posterior probabilities and bootstrap percentages are indicated above and below the branches, respectively. The samples named according to FOC (2011) or NCBI, Stebbins (1940) and the present study are listed from left to right. 
comprised all of the others, including two $S$. glomerata individuals, two $S$. teres C. Shih individuals and all 37 from the $S$. hookeriana complex (BI $=100 \%, \mathrm{BP}=74 \%)$ but there was little resolution within this clade. Excluding S. umbrella, none of the species with multiple individual samples was recovered as monophyletic and S. glomerata samples were present in all three clades.

\section{Combined psbA-trnH and matK sequences}

The combined $p s b A-\operatorname{trn} H$ and mat $K$ sequences measured $870 \mathrm{bp}$, where 54 nucleotide sites were variable and 23 were phylogenetically informative. The $\mathrm{K}-2 \mathrm{P}$ distance is estimated to be $0.2 \%$ on average and ranged from 0 to $1.8 \%$ within the ingroup, while $0.1 \%$ on average or $0.6 \%$ maximally within the complex. The NJ tree was congruent with the $50 \%$ major consensus tree obtained by BI and the latter is presented in Fig. 2. The topology recovered was very similar to that for ITS on the phylogenetic context of $S$. hookeriana complex, but two, one containing $S$. umbrella and the one containing $S$. hookeriana complex, of the three clades based on the ITS sequences, were combined as one.

\section{Combined ITS, psbA-trnH and matK sequences}

ILD test $(\mathrm{P}=0.289000)$ detected no strong evidence of incongruence between the data partitions. Thus, the three fragments are combined and the resulting topologies from NJ and BI (Suppl. material 2) are concordant. Being highly similar to that from ITS, three major clades within Soroseris were recovered and the relationship within $S$. hookeriana complex remains largely unresolved.

\section{Discussion}

Aside from $S$. umbrella, no species were recovered in a monophyletic clade. In particular, $S$. glomerata was revealed to be present in all the three major clades (Figs 1, 2, Suppl. material 2), indicating that the circumscription of this species needed to be revised. All the members of the $S$. hookeriana complex formed a clade together with $S$. teres and part of S. glomerata (Figs 1, 2, Suppl. material 2), without subclades corresponded to the circumscription in the Flora of China or any other systems (Stebbins 1940; Shih 1993). Thus, the complex needs to be expanded to include all these members. However, the poor resolution was not sufficient to aid our selection from the proposed systems, although our results are helpful for understanding the processes or mechanisms responsible for the high variation within the complex.

In most cases, hybridisation is considered to explain the occurrence of intermediates. It is not possible to exclude this mechanism in the $S$. hookeriana complex, but it 
appears to conflict with the status of Soroseris because of the following reasons. First, hybridisation often results in different topologies when phylogenetic trees are reconstructed based on ITS and chloroplast sequences, which was not the case for Soroseris. Second, hybridisation might only affect the tree obtained based on a nuclear marker, but the grouping of the chloroplast sequences was also not species-specific for Soroseris. Third, the occurrence of hybridisation might be determined by the distribution of the parent species, where it usually occurs in areas where the ranges of the two species meet and thus the diversity of these populations might be higher than that of others. We found no evidence of hybridisation based on these three reasons in Soroseris. In addition, mosaic sites in nuclear ITS sequences, which are characteristic of many taxa generated by hybridisation, are rare in Soroseris.

Alternatively, we suggest that radiation might be the main mechanism responsible for the various forms of intermediates in Soroseris. Radiation involves the rapid differentiation of a lineage within a short time interval, which is mostly triggered by environmental change or morphological innovation (Liu et al. 2006). The rapid uplift of the QTP generated a large number of heterogeneous environments and promoted the rapid differentiation of genera such as Rhododendron L. (Milne 2004), Ligularia Cass (Liu et al. 2006) and Saussurea DC (Wang et al. 2009). The main typical characteristic of these genera is a poorly resolved phylogeny with a large number of parallel branches, as well as complicated but subtle morphological variation amongst populations or species (Wang et al. 2009). However, only a few variations might exist within a population or certain region, whereas hybridisation is characterised by high variation within a population (Meeus et al. 2016). In the present study, few morphological variations were detected in each Soroseris population, whereas many were found between populations, particularly in terms of the leaf shape, indumentum in the phyllary and the plant height. Two or more states were present for all three of these characters and various combinations were present in different populations. We consider that all the populations of the $S$. hookeriana complex might have been derived from the same widespread ancestor on the QTP, but various environmental changes following the uplift of the QTP reduced the gene flow amongst most of the populations to yield a number of parallel branches, while adaptation to the local environment also resulted in an array of morphotypes, which were treated as subspecies, possibly under different species, by different systems (Stebbins 1940; Shih 1997; Shi and Kilian 2011).

According to the phylogenetic context and little genetic differentiation (ITS: $0.3 \%$ on average while $1 \%$ maximally; concatenated cp: $0.1 \%$ on average while $0.6 \%$ maximally), all members of the $S$. hookeriana complex (include $S$. teres and part of S. glomerate) could be treated as single species. However, this revision will make it difficult to describe an assemblage. In addition, this treatment might fail to reflect the evolutionary history discussed above and the biodiversity may be underestimated. However, the alternative treatment is also not perfect because separating all of the species will make identification difficult, especially when encountering intermediates, which is common in the field. In order to address these issues, we propose to treat all of the morphotypes, especially those with the typical morphology and widespread distribution, as subspecies of $S$. hookeriana because this is the earliest name of a species reported within the complex. However, we abandoned, for the time being, assigning new names to $S$. teres 
and S. glomerate due to insufficient sampling as well as distinct morphology. In addition, the name $S$. hookeriana subsp. erysimoides (Hand.-Mazz.) Stebbins has been published previously and we suggest that it is restored. Thus, a total of eight taxa, including four new combinations, are proposed and a key is provided in the following.

\section{Key to the possible members of the $S$. hookeriana complex}

1a Cataphylls numerous on the lower part of the stem; leaf blades elliptic or spatulate; ligule of corollas mostly equal to or shorter than the tube. ... S. glomerata (only those closely related to the $S$. hookeriana complex)

1b Cataphylls few or none; leaf blades lanceolate or oblanceolate; ligules distinctly exceeding the tube of the corolla ....................................................... 2

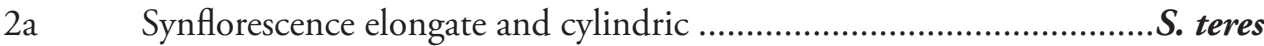

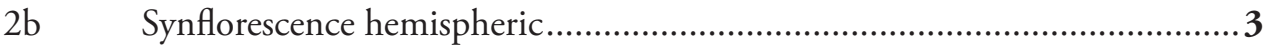

3a Leaves entire or denticulate, obtuse at the apex; upper leaves, bracts of the inflorescence and peduncles glabrous or sparingly hirsute

S. hookeriana subsp. erysimoides

$3 \mathrm{~b} \quad$ Leaves pinnatifid, acute at the apex; upper leaves, bracts of the inflorescence and peduncles strongly hirsutefa. Involucral bracts sparsely to strongly hir-

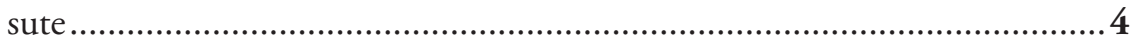

4a Involucral bracts sparsely to strongly hirsute .......................................... 5

5a Leaves sinuate-pinnatifid, sinuate-dentate or merely denticulate; inner bracts sparsely to moderately hirsute

S. hookeriana subsp. occidentalis (new combination)

5b Leaves runcinate-pinnatifid; inner bracts densely hirsute.............................6

6a Stem tall, 4-20 cm; leaf blade pinnately lobed, lobes narrowly triangular .....

S. hookeriana subsp. typica

6b Stem short, less than $6 \mathrm{~cm}$ tall; leaf blade pinnately lobed, lobes irregular

S. hookeriana subsp. hirsuta (new combination)

$4 \mathrm{~b} \quad$ Involucral bracts glabrous

.7

7a Leaf blade $3-8 \mathrm{~cm}$ long, $0.7-1.8 \mathrm{~cm}$ wide

7b Leaf blade $2-4 \mathrm{~cm}$ long, $0.5-1.3 \mathrm{~cm}$ wide

S. hookeriana subsp. gillii (new combination)

S. hookeriana subsp. handelii (new combination)

Soroseris hookeriana subsp. gillii (S.Moore) Yu.J. Wang \& L.M. Heng, comb. et stat. nov.

urn:Isid:ipni.org:names:60477690-2

ECrepis gillii S. Moore in Journ. Bot. 37: 170. 1899 (Syntype: K000250191); 三Soroseris gillii (S. Moore) Stebbins in Mem. Torrey Bot. Club 19 (3): 41. 1940; S. Y. Hu in Quart. Journ. Taiwan Mus. 21 (3-4): 166. 1968; Higher Plants of China 
4: 686, figure 6786. 1975; Flora Reipublicae Popularis Sinicae. 80 (1): 199. 1997; ESoroseris gillii (S. Moore) Stebbins subsp. typica Stebbins in Mem. Torrey Bot. Club. 19 (3): 42. 1940; S. Y. Hu in Quart. Journ. Taiwan Mus. 21 (3-4): 166. 1968; ESoroseris trichocarpa (Franch.) Shih in Act. Phytotax. Sin 31: 446. 1993; Flora Reipublicae Popularis Sinicae. 80 (1): 199. 1997.

Soroseris hookeriana subsp. hirsuta (J.Anthony) Yu.J. Wang \& L.M. Heng, comb. et stat. nov.

urn:lsid:ipni.org:names:77192776-1

ECrepis gillii S. Moore var. hirsuta J. Anthony in Notes Royal Bot. Gard. Edinb. 18: 193. 1934 (Syntype: E00383690); 三Soroseris gillii (S. Moore) Stebbins subsp. hirsuta (J. Anthony) Stebbins in Mem. Torrey Bot. Club 19 (3): 44.1940 (Syntype: E00383690); S. Y. Hu in Quart. Journ. Taiwan Mus. 21 (3-4): 166. 1968; 三Soroseris hirsuta (J. Anthony) C. Shih in Act. Phytotax. Sin 31: 446.1993; Flora Reipublicae Popularis Sinicae. 80 (1): 201. 1997.

Soroseris hookeriana subsp. occidentalis (Stebbins) Yu.J. Wang \& L.M. Heng, comb. nov.

urn:lsid:ipni.org:names:60477691-2

ESoroseris gillii subsp. occidentalis Stebbins in Mem. Torrey Bot. Club. 19 (3): 44. 1940 (Type: K000250154); Babcock in Univ. Calif. Publ. Bot. 22: 922. 1937; S. Y. Hu in Quart. Journ. Taiwan Mus. 21 (3-4): 166. 1968; ESoroseris occidentalis (Stebbins) Tzvelev in Bot. Zhurn. 92: 1753. 2007.

Soroseris hookeriana subsp. handelii (Stebbins) Yu.J. Wang \& L.M. Heng, comb. nov. urn:Isid:ipni.org:names:77192779-1

ESoroseris gillii subsp. handelii Stebbins in Mem. Torrey Bot. Club. 19 (3): 42.1940

(Isotype: E00383689); S. Y. Hu in Quart. Journ. Taiwan Mus. 21 (3-4): 166. 1968.

\section{Acknowledgements}

We thank Jian-Quan Liu and Zhong-Hu Li for helping with our field investigation. We are very grateful to Dr. Christina Flann and Dr. Rob Smissen for their valuable comments that contributed greatly to our manuscript. This study was supported by the National Natural Science Foundation of China (81274024). 


\section{References}

Akaike H (1974) A new look at the statistical model identification. IEEE Transactions on Automatic Control 19(6): 716-723. https://doi.org/10.1109/TAC.1974.1100705

Darriba D, Taboada GL, Doallo R, Posada D (2012) jModelTest 2: More models, new heuristics and parallel computing. Nature Methods 9(8): 772. https://doi.org/10.1038/ nmeth.2109

Doyle JJ, Dickson EE (1987) Preservation of Plant Samples for DNA Restriction Endonuclease Analysis. Taxon 36: 715-722. https://doi.org/10.2307/1221122

Farris JS, Kallersjo M, Kluge AG, Bult C (1995) Constructing a Significance Test for Incongruence. Systematic Biology 44: 570-572. https://doi.org/10.1093/sysbio/44.4.570

Ford CS, Ayres KL, Toomey N, Haider N, Stahl JVA, Kelly LJ, Wikström N, Hollingsworth PM, Duff RJ, Hoot SB (2009) Selection of candidate coding DNA barcoding regions for use on land plants. Botanical Journal of the Linnean Society 159(1): 1-11. https://doi. org/10.1111/j.1095-8339.2008.00938.x

Hall TA (1999) BioEdit: A user-friendly biological sequence alignment editor and analysis program for Windows 95/98/NT. Nucleic Acids Symposium Series 41: 95-98.

Kimura M (1980) A simple method for estimating evolutionary rates of base substitutions through comparative studies of nucleotide sequences. Journal of Molecular Evolution 16(2): 111-120. https://doi.org/10.1007/BF01731581

Liu J-Q (2016) “The integrative species concept" and "species on the speciation way". Shengwu Duoyangxing 24(9): 1004-1008. https://doi.org/10.17520/biods.2016222

Liu J-Q, Wang Y-J, Wang A-L, Hideaki O, Abbott R (2006) Radiation and diversification within the Ligularia-Cremanthodium-Parasenecio complex (Asteraceae) triggered by uplift of the Qinghai-Tibetan Plateau. Molecular Phylogenetics and Evolution 38(1): 31-49. https://doi.org/10.1016/j.ympev.2005.09.010

Meeus S, Janssens S, Helsen K, Jacquemyn H (2016) Evolutionary trends in the distylous genus Pulmonaria (Boraginaceae): Evidence of ancient hybridization and current interspecific gene flow. Molecular Phylogenetics and Evolution 98: 63-73. https://doi.org/10.1016/j. ympev.2015.11.022

Milne RI (2004) Phylogeny and biogeography of Rhododendron subsection Pontica, a group with a tertiary relict distribution. Molecular Phylogenetics and Evolution 33(2): 389-401. https://doi.org/10.1016/j.ympev.2004.06.009

Peng Y-L, Gao X-F, Peng L (2013) Pollen morphology of Youngia and six related genera (Asteraceae: Cichorieae) and its systematic significance. Phytotaxa 139(1): 36-62. https://doi. org/10.11646/phytotaxa.139.1.2

Ronquist F, Klopfstein S, Vilhelmsen L, Schulmeister S, Murray DL, Rasnitsyn AP (2012) A total-evidence approach to dating with fossils, applied to the early radiation of the Hymenoptera. Systematic Biology 61(6): 973-999. https://doi.org/10.1093/sysbio/sys058

Sang T, Crawford DJ, Stuessy TF (1997) Chloroplast DNA phylogeny, reticulate evolution, and biogeography of Paeonia (Paeoniaceae). American Journal of Botany 84(8): 11201136. https://doi.org/10.2307/2446155 
Shi Z, Kilian N (2011) Soroseris (Asteraceae-Lactuceae). In: Hong DY, Raven PH (Eds) Flora of China. Science Press, St. Louis, Missouri Botanical Garden Press, Beijing, 343-345.

Shih C (1993) Taxonomic study on genera of tribe Lactuceae (Compositae) from China. Zhiwu Fenlei Xuebao 31: 432-450.

Shih C (1997) Soroseris Stebbins. In: Ling Y, Shih C (Eds) Flora Reipublicae Popularis Sinicae. Science Press, Beijing, 194-208.

Stebbins GL (1940) Studies in the Cichorieae: Dubyaea and Soroseris, endemics of the SinoHimalayan region. Memoirs of the Torrey Botanical Club 19: 1-76.

Su X, Wu G-L, Li L-L, Liu J-Q (2015) Species delimitation in plants using the Qinghai-Tibet Plateau endemic Orinus (Poaceae:Tridentinae) as an example. Annals of Botany 116(1): 35-48. https://doi.org/10.1093/aob/mcv062

Swofford D (2003) PAUP*: phylogenetic analysis using parsimony (*and other methods), Version 4.0b 10. Sinauer Associates, Sunderland, Massachusetts.

Tamura K, Stecher G, Peterson D, Filipski A, Kumar S (2013) MEGA6: Molecular Evolutionary Genetics Analysis Version 6.0. Molecular Biology and Evolution 30(12): 2725-2729. https://doi.org/10.1093/molbev/mst197

Thompson JD, Gibson TJ, Plewniak F, Jeanmougin F, Higgins DG (1997) The CLUSTAL_X windows interface: Flexible strategies for multiple sequence alignment aided by quality analysis tools. Nucleic Acids Research 25(24): 4876-4882. https://doi.org/10.1093/nar/25.24.4876

Tzvelev NN (2007) New taxa and new combinations in Asteraceae from Central Asia. Botanicheskii Zhurnal (Moscow \& Leningrad) 92(11): 1747-1757.

Wang Y-J, Li X-J, Hao G, Liu J-Q (2004) Molecular phylogeny and biogeography of Androsace (Primulaceae) and the convergent evolution of cushion morphology. Zhiwu Fenlei Xuebao 6: 481-499.

Wang Y-J, Susanna A, Raabstraube EV, Milne R, Liu J-Q (2009) Island-like radiation of Saussurea (Asteraceae: Cardueae) triggered by uplifts of the Qinghai-Tibetan Plateau. Biological Journal of the Linnean Society. Linnean Society of London 97(4): 893-903. https://doi. org/10.1111/j.1095-8312.2009.01225.x

White TJ, Bruns TD, Lee SB, Taylor JW, Innis MA, Gelfand DH, Sninsky JJ (1990) Amplification and direct sequencing of fungal ribosomal RNA genes for phylogenetics, 315-322.

Yang Q-E (2016) Comments on species-level taxonomy of plants in China. Shengwu Duoyangxing 24(9): 1024-1030. https://doi.org/10.17520/biods.2016226

Yang H-X, Su F-M, Sun W-G, Zhang Y-H, Li Z-M (2017) A supplementary of chromosomal studies on an endemic genus Soroseris (Asteraceae: Lactuceae) from the Qinghai-Tibet Plateau. Botanical Research 06(01): 17-24. https://doi.org/10.12677/BR.2017.61004

Ying L, Yang Q-E (2011) Cytology and its systematic implications in Sinosenecio (SenecioneaeAsteraceae) and two closely related genera. Plant Systematics and Evolution 291(1-2): 7-24. https://doi.org/10.1007/s00606-010-0365-3

Zhang J-W, Sun H (2011) Parasyncalathium J.W. Zhang, Boufford \&amp; H. Sun (Asteraceae, Cichorieae): A new genus endemic to the Himalaya-Hengduan Mountains. Taxon 60: 1678-1684.

Zhang J-W, Sun H, Nie Z-L (2007) Karyological studies on the Sino-Himalayan endemic Soroseris and two related genera of tribe Lactuceae (Asteraceae). Botanical Journal of the Linnean Society 154(1): 79-87. https://doi.org/10.1111/j.1095-8339.2007.00644.x 
Zhang J-W, Nie Z-L, Wen J, Sun H (2011) Molecular phylogeny and biogeography of three closely related genera, Soroseris, Stebbinsia, and Syncalathium (Asteraceae, Cichorieae), endemic to the Tibetan Plateau, SW China. Taxon 60: 15-26.

Zhang J-W, Boufford DE, Sun H (2013) Systematic significance of achene morphology in Soroseris, Syncalathium and Parasyncalathium (Asteraceae: Cichorieae). Botanical Journal of the Linnean Society 173(3): 476-486. https://doi.org/10.1111/boj.12046

Zheng H-L, Fan L-Q, Milne RI, Zhang L, Wang Y-L, Mao K-S (2017) Species Delimitation and Lineage Separation History of a Species Complex of Aspens in China. Frontiers of Plant Science 8: 375. https://doi.org/10.3389/fpls.2017.00375

\section{Suppl. material I}

The main morphological difference amongst members of the Soroseris hookeriana complex and the closely related species

Authors: La-Mei Heng, Yu-Lin Zheng, Yong-Bao Zhao, Yu-Jin Wang

Data type: measurement

Copyright notice: This dataset is made available under the Open Database License (http://opendatacommons.org/licenses/odbl/1.0/). The Open Database License $(\mathrm{ODbL})$ is a license agreement intended to allow users to freely share, modify, and use this Dataset while maintaining this same freedom for others, provided that the original source and author(s) are credited.

Link: https://doi.org/10.3897/phytokeys.114.29914.suppl1

\section{Suppl. material 2}

The 50\% majority rule consensus tree derived from Bayesian inference of the combined sequences of nuclear internal transcribed spacer, psbA-trnH and matK

Authors: La-Mei Heng, Yu-Lin Zheng, Yong-Bao Zhao, Yu-Jin Wang

Data type: molecular data

Explanation note: Posterior probabilities and bootstrap percentages are indicated above and below the branches, respectively. The samples named according to FOC (2011) or NCBI, Stebbins (1940) and the present study are listed from left to right.

Copyright notice: This dataset is made available under the Open Database License (http://opendatacommons.org/licenses/odbl/1.0/). The Open Database License $(\mathrm{ODbL})$ is a license agreement intended to allow users to freely share, modify, and use this Dataset while maintaining this same freedom for others, provided that the original source and author(s) are credited.

Link: https://doi.org/10.3897/phytokeys.114.29914.suppl2 